\title{
FAKTOR YANG BERHUBUNGAN DENGAN KEJADIAN PARTUS LAMA PADA IBU BERSALIN DI RSU HAJI MEDAN TAHUN 2014
}

\author{
Lusiana Gultom \\ Jurusan Kebidanan Poltekkes Kemenkes Medan
}

\begin{abstract}
Abstrak
Salah satu penyebab langsung tingginya AKI di Indonesia ialah partus lama (9\%) yang banyak ditemukan pada kelainan letak janin, CPD, kelainan his, dan KPD. Penelitian ini bertujuan untuk mengetahui faktor faktor yang berhubungan dengan kejadian partus lama pada ibu bersalin. Penelitian ini bersifat analitik menggunakan data sekunder dari rekam medik di RSU Haji Medan periode Januari - Desember 2014. Sampel dalam penelitian untuk kasus dan kontrol berjumlah 80 dengan menggunakan sistematic random sampling. Hasil penelitian menunjukkan ada hubungan yang bermakna antara umur dengan partus lama $(p=0,002), O R=3,586$. Ada hubungan bermakna antara paritas dengan partus lama $(p=0,000), O R=7,013$. Ada hubungan bermakna antara kelainan his dengan partus lama $(p=0,000), O R=35,909$. Adanya hubungan yang bermakna antara CPD dengan partus lama $(p=0,000)$. Adanya hubungan bermakna antara KPD dengan partus lama $(p=0,001), O R=15,33$. Adanya hubungan bermakna antara kelainan letak janin dengan partus lama $(p=0,000), O R=13,00$. Disimpulkan bahwa umur, paritas, kelainan his, CPD, KPD, dan kelainan letak janin memiliki hubungan dengan partus lama. Disarankan kepada Organisasi Profesi dan pihak RSU Haji Medan meningkatkan kegiatan seminar dan pelatihan khusus pada seluruh tenaga kesehatan baik mandiri maupun komunitas dalam pencegahan dan penanganan rujukan cepat kasus partus lama.
\end{abstract}

Kata kunci : Partus Lama, Ibu Bersalin

\section{PENDAHULUAN}

\section{Latar Belakang}

Pelayanan kebidanan yang baik atau buruk dalam suatu negara dapat dinilai dari jumlah AKI (Angka Kematian Ibu) yang di mulai dari masa kehamilan, persalinan, dan nifas serta jumlah AKB (Angka Kematian Bayi) yaitu fase antara kelahiran hingga bayi belum mencapai umur 1 tahun. Namun kenyataannya, angka kematian tersebut meningkat dilihat dari jumlah kematian ibu di seluruh dunia sebesar 500.000 jiwa per tahun dan kematian bayi khususnya neonatus sebesar 10.000.000 jiwa per tahun. Sebanyak 99 persen kematian ibu akibat masalah persalinan atau kelahiran yang terjadi di negaranegara berkembang. Rasio kematian ibu di negara-negara berkembang merupakan tertinggi dengan 450 kematian ibu per 100.000 kelahiran hidup jika dibandingkan dengan rasio kematian ibu di sembilan negara maju dan 51 negara persemakmuran (WHO, 2010).

Di Indonesia, rata-rata AKI tercatat mencapai 359 per 100.000 kelahiran hidup. Rata-rata kematian ini melonjak lebih tinggi dibanding hasil SDKI 2007 yang mencapai 228 per 100.000 . Hal ini masih sangat jauh dalam pencapaian MDGs 2015 untuk target AKI 102 per $100.000 \mathrm{KH}$. Penyebab kematian ibu tersebut telah dirinci menjadi dua, yaitu penyebab langsung dan penyebab tidak langsung. Penyebab langsung Perdarahan (42\%), Eklampsi/Preeklampsi (13\%), Abortus (11\%), Infeksi (10\%), Partus lama / persalinan macet (9\%), dan Penyebab lain (15\%). Penyebab tidak langsung ialah pendidikan, sosial ekonomi dan sosial budaya yang rendah, empat terlalu dalam melahirkan dan tiga terlambat (SDKI, 2012). Berdasarkan laporan dari profil kabupaten / kota AKI yang dilaporkan di Sumatera Utara hanya 123/100.000 kelahiran hidup, namun ini belum bisa menggambarkan AKI yang sebenarnya di populasi. Berdasarkan estimasi bahwa AKI di Sumatera Utara tahun 2008 adalah 290/100.000 kelahiran hidup (Dinkes, Provinsi Sumatera Utara 2008).

Salah satu faktor yang sering menyebabkan morbiditas maupun mortalitas pada ibu bersalin adalah partus lama. Partus lama atau sering disebut partus macet ialah persalinan yang berlangsung lebih dari 24 jam pada primipara dan lebih dari 18 jam pada multipara dengan fase laten lebih dari 8 jam dan dilatasi serviks yang lambat hingga di kanan garis waspada pada partograf (Prawirohardjo, 2007; Wahyuningsih, 2010).

Berdasarkan hasil penelitian Dipta, TP (2010), di RSIA Badrul Aini Medan tahun 2002-2006 diperoleh proporsi partus tak maju $12,7 \%$ yaitu 411 kasus dari 3.225 persalinan dan CFR bayi akibat partus tak maju 0,2\%, di RS Santa Elisabeth Medan tahun 2005 - 2009 ditemukan proporsi partus tak maju 25,2\% yaitu 615 kasus dari 2.436 persalinan. Pada umumnya kehamilan yang sudah terdeteksi dengan risiko tinggi yang dapat menimbulkan partus tak maju harus segera mendapatkan perawatan di rumah sakit sehingga penanganan dapat segera dilakukan.

Partus lama masih banyak terjadi dan keadaan ini menyebabkan angka kesakitan dan angka kematian ibu dan anak masih tinggi dan harus diupayakan mencegah 
terjadinya partus lama tersebut. Partus lama / macet dapat ditemukan pada masalah kelainan letak janin, CPD (ketidaksesuaian besar janin dengan ukuran panggul ibu), kelainan his, dan KPD. Partus lama atau macet masih sering terjadi akibat faktor tambahan seperti terlalu banyak anak namun bisa juga terjadi pada primi, partus pada usia dini atau lanjut (Dipta, TP, 2010).

Hasil penelitian Handa dan Laros dalam Prawirohardjo, 2011, mendiagnosis kemacetan fase aktif (tidak ada pembukaan selama 2 jam atau lebih) pada 5 persen nulipara aterm. Insiden ini belum berubah sejak tahun 1990-an. Kelainan his dengan his yang kurang adekuat berhubungan dengan kejadian partus lama dimana kurang dari 180 satuan Montevideo, didiagnosis pada 80 persen ibu dengan kemacetan fase aktif selama persalinan.

Penelitian di Nigeria Utara dari seluruh ibu yang mengalami persalinan macet, proporsi wanita dengan panggul sempit memiliki tinggi badan $<145 \mathrm{~cm}$ sebesar $40 \%$, tinggi badan $150 \mathrm{~cm}$ sebesar $14 \%$ dan tinggi badan $160 \mathrm{~cm}$ sebesar $1 \%$. Penelitian Park, dkk menyimpulkan bahwa wanita dengan Ketuban Pecah Dini mempunyai rata - rata durasi waktu kala II persalinan yang lebih lama dan mempunyai angka persalinan seksio sesarea yang lebih tinggi karena kegagalan kemajuan persalinan daripada wanita dengan ketuban utuh (Farihaalthafunnisa,2011). Hasil penelitian Eka Trismiyana, dkk di RSUD Dr. H. Abdul Moeloek Propinsi Lampung 2011, menunjukan adanya hubungan signifikan letak janin dengan partus lama $(p=0,000)$ Odd Rasio (OR) $=4,5$.

Hasil survei awal yang dilakukan oleh peneliti di RSU HAJI Medan bahwasanya total dari seluruh persalinan selama tahun 2012 terdapat $121(18,88 \%)$ kasus partus lama / macet dari 641 persalinan, dan tahun 2013 terdapat $99(16,5 \%)$ kasus persalinan lama / macet dari 600 persalinan (Medical Record, 2013). Berdasarkan uraian permasalahan di atas, maka peneliti tertarik untuk melakukan penelitian tentang "Faktor - Faktor yang Berhubungan dengan Kejadian Partus Lama pada Ibu Bersalin di RSU HAJI Medan Tahun 2014“.

\section{TUJUAN PENELITIAN}

\section{Tujuan Umum}

Untuk mengetahui Faktor - Faktor yang Berhubungan dengan Kejadian Partus Lama pada Ibu Bersalin di RSU HAJI Medan Tahun 2014

\section{Tujuan Khusus}

1. Untuk mengetahui distribusi kejadian partus lama pada ibu bersalin berdasarkan kriteria ibu (umur, paritas, kelainan his, CPD, dan KPD) dan kriteria janin (kelainan letak) di RSU HAJI Medan Tahun 2014

2. Untuk mengetahui hubungan umur dengan Kejadian Partus Lama pada Ibu Bersalin di RSU HAJI Medan Tahun 2014

3. Untuk mengetahui hubungan Paritas dengan Kejadian Partus Lama pada Ibu Bersalin di RSU HAJI Medan Tahun 2014
4. Untuk mengetahui hubungan kelainan his dengan kejadian partus lama pada ibu bersalin di RSU HAJI Medan Tahun 2014

5. Untuk mengetahui hubungan CPD dengan Kejadian Partus Lama pada Ibu Bersalin di RSU HAJI Medan Tahun 2014

6. Untuk mengetahui hubungan KPD dengan Kejadian Partus Lama pada Ibu Bersalin di RSU HAJI Medan Tahun 2014

7. Untuk mengetahui hubungan kelainan letak janin dengan Kejadian Partus Lama pada Ibu Bersalin di RSU HAJI Medan Tahun 2014

\section{METODE PENELITIAN}

\section{Jenis dan Desain Penelitian}

Jenis penelitian ini merupakan jenis penelitian analitik dengan menggunakan desain case control dimana yang menjadi kasus ialah ibu bersalin dengan partus lama dan yang menjadi kontrol ialah ibu bersalin bukan dengan kejadian partus lama dengan tujuan untuk mengetahui faktor - faktor yang berhubungan dengan kejadian partus lama pada ibu bersalin dengan melihat hasil data rekam medik di RSU HAJI Medan Tahun 2013 (Notoadmojo, 2010).

\section{Lokasi dan Waktu Penelitian}

Penelitian ini dilakukan di RSU HAJI Medan pada bulan Desember 2014 sampai April 2015.

\section{Populasi dan sampel penelitian}

Populasi dalam penelitian ini adalah semua Ibu yang bersalin dan dirawat di Rumah Sakit Umum Haji Medan tahun 2014 periode 1 Januari 2014 sampai 31 Desember 2014 sebanyak 600 orang, populasi kasus 99 orang yaitu semua ibu bersalin dengan partus lama, dan populasi kontrol 501 orang adalah semua ibu bersalin yang dengan tidak partus lama. Dalam menetapkan sampel, peneliti menetapkan kriteria yang diambil sebagai sampel. Kriteria inklusi kasus dari data ibu yang bersalin dengan partus lama dan di rawat di Rumah Sakit Umum Haji Medan. Kriteria eksklusi kasus data ibu yang bersalin dengan partus lama dan dan di rawat di RSU Haji Medan dengan catatan medik yang tidak lengkap.

Dari populasi Kasus yang berjumlah 99, Maka besar sampel dapat dihitung dengan menggunakan rumusdibawah ini(Notoatmodjo, 2005).

$$
\mathrm{n}=\frac{\mathrm{N}}{1+\mathrm{N}\left(\mathrm{d}^{2}\right)}
$$

Maka besar sampel sebanyak 80 .

Besar sampel kelompok kasus dan kelompok kontrol adalah 1:1 maka sampel dalam penelitian ini 160 .

Teknik pengambilan sampel secara acak sistematis (systematic random sampling).

\section{Jenis dan Cara Pengumpulan Data}

Penelitian ini menggunakan data sekunder yaitu data yang diperoleh dari rekam medik ibu bersalin dengan kasus partus lama maupun tidak dengan kasus partus lama di RSU Haji Medan periode Januari - Desember 2014. 
Dan cara pengumpulan datanya menggunakan dummy tabel dalam bentuk checklist sesuai dengan data rekam medik.

\section{HASIL DAN PEMBAHASAN}

\section{Hasil Penelitian}

Hasil Analisis Univariat

Gambaran dari Faktor - Faktor yang berhubungan dengan Kejadian partus lama akan dijabarkan pada tabel 1.1. berikut.

Tabel 1.1

Distribusi Responden Menurut Faktor YangBerhubungan dengan Kejadian Partus Lama di RSU HAJI Medan Tahun 2014.

\begin{tabular}{|c|c|c|c|c|}
\hline \multirow{2}{*}{ FaktorPenyebabPartus Lama } & \multicolumn{2}{|l|}{ Kasus } & \multicolumn{2}{|c|}{ Kontrol } \\
\hline & $\mathrm{N}$ & $\%$ & $\mathrm{~N}$ & $\%$ \\
\hline \multicolumn{5}{|l|}{ Umur } \\
\hline$<20$ atau $>35$ & 25 & 31,25 & 9 & 11,25 \\
\hline $20-35$ & 55 & 68,75 & 71 & 88,75 \\
\hline Total & 80 & 100,00 & 80 & 100,00 \\
\hline \multicolumn{5}{|l|}{ Paritas } \\
\hline 1 atau $>3$ & 29 & 36,25 & 6 & 7,50 \\
\hline $2-3$ & 51 & 63,75 & 74 & 92,50 \\
\hline Total & 80 & 100,00 & 80 & 100,00 \\
\hline \multicolumn{5}{|l|}{ Kelainan His } \\
\hline $\mathrm{Ya}$ & 25 & 31,25 & 1 & 1,25 \\
\hline Tidak & 55 & 68,75 & 79 & 98,75 \\
\hline Total & 80 & 100,00 & 80 & 100,00 \\
\hline \multicolumn{5}{|l|}{ CPD } \\
\hline $\mathrm{Ya}$ & 22 & 27,50 & 0 & 0 \\
\hline Tidak & 58 & 72,50 & 80 & 100 \\
\hline Total & 80 & 100,00 & 80 & 100,00 \\
\hline \multicolumn{5}{|l|}{ KPD } \\
\hline $\mathrm{Ya}$ & 13 & 16,25 & 1 & 1,25 \\
\hline Tidak & 67 & 83,75 & 79 & 98,75 \\
\hline Total & 80 & 100 & 80 & 100 \\
\hline \multicolumn{5}{|l|}{ Kelainan Letak } \\
\hline $\mathrm{Ya}$ & 20 & 25 & 2 & 2,5 \\
\hline Tidak & 60 & 75 & 78 & 97,5 \\
\hline Total & 80 & 100 & 80 & 100 \\
\hline
\end{tabular}

\section{Hasil Analisis Bivariat}

Tabel 1.2.

Hubungan Umur Ibu Bersalin dengan Kejadian Partus Lama di RSU HAJI Medan Tahun 2014.

\begin{tabular}{|c|c|c|c|c|c|c|c|}
\hline \multirow{3}{*}{$\mathrm{NO}$} & \multirow{3}{*}{ Umur Ibu } & \multicolumn{4}{|c|}{ Partus Lama } & \multirow{3}{*}{$p$ value } & \multirow{3}{*}{$\begin{array}{c}O R \\
(95 \% C I)\end{array}$} \\
\hline & & \multicolumn{2}{|c|}{ Kasus } & \multicolumn{2}{|c|}{ Kontrol } & & \\
\hline & & $\mathrm{N}$ & $\%$ & $\mathrm{~N}$ & $\%$ & & \\
\hline 1 & $<20$ atau $>35$ & 25 & 31,25 & 9 & 11,25 & \multirow{3}{*}{0,002} & \multirow{3}{*}{$\begin{array}{c}3,586 \\
(1,549-8,300)\end{array}$} \\
\hline 2 & $20-35$ & 55 & 68,75 & 71 & 88,75 & & \\
\hline & Total & 80 & 100,00 & 80 & 100,00 & & \\
\hline
\end{tabular}

Tabel 1.3.

Hubungan Paritas Ibu Bersalin dengan Kejadian Partus Lama di RSU HAJI Medan Tahun 2014.

\begin{tabular}{|c|c|c|c|c|c|c|c|}
\hline \multirow{3}{*}{ NO } & \multirow{3}{*}{ Paritas } & \multicolumn{4}{|c|}{ Partus Lama } & \multirow{3}{*}{$P$ value } & \multirow{3}{*}{$\begin{array}{c}O R \\
(95 \% C I)\end{array}$} \\
\hline & & \multicolumn{2}{|c|}{ Kasus } & \multicolumn{2}{|c|}{ Kontrol } & & \\
\hline & & $\mathrm{N}$ & $\%$ & $\mathrm{~N}$ & $\%$ & & \\
\hline 1 & 1 atau $>3$ & 29 & 36,25 & 6 & 7,50 & \multirow{3}{*}{0,000} & \multirow{3}{*}{$\begin{array}{c}7,013 \\
(2,71-18,11)\end{array}$} \\
\hline 2 & $2-3$ & 51 & 63,75 & 74 & 92,50 & & \\
\hline & Total & 80 & 100,00 & 80 & 100,00 & & \\
\hline
\end{tabular}


Tabel 1.4.

Hubungan Kelainan His dengan Kejadian Partus Lama di RSU HAJI Medan Tahun 2014.

\begin{tabular}{|c|c|c|c|c|c|c|c|}
\hline \multirow{3}{*}{ NO } & \multirow{3}{*}{$\begin{array}{c}\text { Kelainan } \\
\text { His }\end{array}$} & \multicolumn{4}{|c|}{ Partus Lama } & \multirow{3}{*}{$p$ value } & \multirow{3}{*}{$\begin{array}{c}O R \\
(95 \% C I)\end{array}$} \\
\hline & & \multicolumn{2}{|c|}{ Kasus } & \multicolumn{2}{|c|}{ Kontrol } & & \\
\hline & & $\mathrm{N}$ & $\%$ & $\mathrm{~N}$ & $\%$ & & \\
\hline 1 & $\mathrm{Ya}$ & 25 & 31,25 & 1 & 1,25 & \multirow{3}{*}{0,000} & 35,909 \\
\hline \multirow[t]{2}{*}{2} & Tidak & 55 & 68,75 & 79 & 98,75 & & $(4,725-$ \\
\hline & Total & 80 & 100,00 & 80 & 100,00 & & $272,923)$ \\
\hline
\end{tabular}

Tabel 1.4.

Hubungan CPD dengan Kejadian Partus Lama di RSU HAJI Medan Tahun 2014

\begin{tabular}{|c|c|c|c|c|c|c|}
\hline \multirow{3}{*}{ NO } & \multirow{3}{*}{ CPD } & \multicolumn{4}{|c|}{ Partus Lama } & \multirow{3}{*}{$p$ value } \\
\hline & & \multicolumn{2}{|c|}{ Kasus } & \multicolumn{2}{|c|}{ Kontrol } & \\
\hline & & $\mathrm{N}$ & $\%$ & $\mathrm{~N}$ & $\%$ & \\
\hline 1 & $\mathrm{Ya}$ & 22 & 27,50 & 0 & 0 & \\
\hline \multirow[t]{2}{*}{2} & Tidak & 58 & 72,50 & 80 & 100 & 0,000 \\
\hline & Total & 80 & 100,00 & 80 & 100,00 & \\
\hline
\end{tabular}

Tabel 1.6.

Hubungan KPD dengan Kejadian Partus Lama di RSU HAJI Medan Tahun 2014.

\begin{tabular}{|c|c|c|c|c|c|c|c|}
\hline \multirow{3}{*}{$\mathrm{NO}$} & \multirow{3}{*}{ KPD } & \multicolumn{4}{|c|}{ Partus Lama } & \multirow{3}{*}{$p$ value } & \multirow{3}{*}{$\begin{array}{c}O R \\
(95 \% C I)\end{array}$} \\
\hline & & \multicolumn{2}{|c|}{ Kasus } & \multicolumn{2}{|c|}{ Kontrol } & & \\
\hline & & $\mathrm{N}$ & $\%$ & $\mathrm{~N}$ & $\%$ & & \\
\hline 1 & $\mathrm{Ya}$ & 13 & 16,25 & 1 & 1,25 & \multirow{3}{*}{0,001} & \multirow{3}{*}{$\begin{array}{c}15,33 \\
(1,95-120,25)\end{array}$} \\
\hline 2 & Tidak & 67 & 83,75 & 79 & 98,75 & & \\
\hline & Total & 80 & 100,00 & 80 & 100,00 & & \\
\hline
\end{tabular}

Tabel 1.7.

Hubungan Kelainan Letak Janin dengan Kejadian Partus Lama di RSU HAJI Medan Tahun 2014.

\begin{tabular}{cccccccc}
\hline \multirow{2}{*}{ NO } & \multirow{2}{*}{$\begin{array}{c}\text { Kelainan } \\
\text { Letak Janin }\end{array}$} & \multicolumn{3}{c}{ Kasus } & \multirow{2}{c}{ Partus Lama } & & \multirow{2}{*}{ OR } \\
\cline { 3 - 5 } & & $\mathrm{N}$ & $\%$ & $\mathrm{~N}$ & $\%$ & value & $(95 \%$ CI $)$ \\
\hline 1 & Ya & 20 & 25,00 & 2 & 2,50 & & 13,0 \\
2 & Tidak & 60 & 75,00 & 78 & 97,50 & \multirow{2}{*}{0,000} & $(2,92-57,8)$ \\
\hline & Total & 80 & 100,00 & 80 & 100,00 & & \\
\hline
\end{tabular}

\section{PEMBAHASAN}

Distribusi Kejadian Partus Lama Berdasarkan umur, paritas, kelainan his, CPD, KPD, dan kelainan letak di RSU HAJI Medan Tahun 2014

Hasil penelitian yang berjudul Faktor - Faktor Berhubungan dengan kejadian partus lama pada ibu bersalin di RSU Haji Medan Tahun 2013, dapat diketahui bahwa dari 80 responden sebagai kasus yang mengalami partus lama, lebih banyak pada umur 20-35 tahun sebesar 55 orang $(68,75)$, sedangkan ibu dengan umur $<20$ atau $>35$ tahun sebesar 25 orang $(31,25 \%)$.

Umur ialah usia individu yang terhitung mulai saat dilahirkan sampai saat berulang tahun terakhir. Umur ibu kurang dari 20 tahun dan lebih dari 35 tahun memiliki resiko tinggi yang kemungkinan akan memberikan ancaman kesehatan dan jiwa ibu maupun janin yang dikandungnya selama kehamilan, persalinan dan nifas (Mochtar, 2011). Sejalan dengan pendapat mochtar bahwa umur mempunyai pengaruh terhadap kehamilan dan persalinan dimana umur reproduksi sehat atau dikenal dengan usia aman untuk kehamilan dan persalinan adalah umur 20 sampai 35 tahun.

Hasil penelitian dapat diketahui bahwa dari 80 responden sebagai kasus yang mengalami partus lama lebih banyak ibu mengalami partus lama pada paritas 2-3 sebesar 51 orang $(63,75)$, sedangkan ibu dengan paritas 1 atau $>3$ sebesar 29 orang $(36,25 \%)$.

Paritas atau para adalah wanita yang pernah melahirkan bayi aterm dengan kelahiran hidup atau lahir mati. Mempunyai anak lebih dari empat orang juga akan menambah resiko terhadap ibu dan bayinya, lebih - lebih jarak antara kehamilan kurang dari dua tahun, maka ibu akan lemah akibat seringnya hamil, melahirkan, menyusui, dan merawat anak - anaknya sehingga mengakibatkan berbagai masalah(Manuaba, 2010). Sejalan dengan pendapat Manuaba bahwa paritas adalah jumlah anak yang pernah dilahirkan oleh seorang ibu baik hidup maupun mati.

Hasil penelitian dapat diketahui bahwa dari 80 responden sebagai kasus yang mengalami partus lama lebih banyak ibu mengalami partus lama dengan tidak 
CPD sebesar 58 orang (72,50\%), sedangkan ibu dengan CPD sebesar 22 orang $(27,50 \%)$.

CPD (SefalopelvikDisproporsi) adalah ketidakmampuan janin untuk melewati panggul.kondisi luas panggul ibu tidak sebanding dengan kepala bayi, sehingga pembukaannya berjalan lambat dan akan menimbulkan komplikasi obstetri (Dipta, TP 2010). Sejalan dengan pendapat Dipta, TP bahwa panggul merupakan faktor penting dalam proses persalinan dimana besarnya kepala janin dalam perbandingan luasnya panggul ibu menentukan apakah ada disproporsi sefalopelvik atau tidak.

Hasil penelitian dapat diketahui bahwa dari 80 responden sebagai kasus yang mengalami partus lama lebih banyak ibu mengalami partus lama dengan tidak KPD sebesar 67 orang $(83,75)$, sedangkan ibu dengan KPD sebesar 13 orang (16,25\%). KPD (Ketuban Pecah Dini) didefinisikan sebagai pecahnya ketuban sebelum waktunya melahirkan yang dibagi menjadi KPD preterm yaitu KPD sebelum usia kehamilan 37 minggu dan KPD yang memanjang yaitu KPD yang terjadi lebih dari 12 jam sebelum waktunya melahirkan (Rukiyah, Aiyeyeh, 2010). Sejalan dengan pendapat Rukiyah bahwa KPD akan menyebabkan persalinan berlangsung lebih dari 12 jam sehingga akan semakin berisiko untuk mengalami partus lama.

Hasil penelitian dapat diketahui bahwa dari 80 responden sebagai kasus yang mengalami partus lama lebih banyak ibu mengalami partus lama dengan tidak kelainan letak janin sebesar 60 orang $(75,00 \%)$, sedangkan ibu dengan kelainan letak janin sebesar 20 orang $(25,00 \%)$. Kelainan letak janin adalah posisi janin dalam rahim yang tidak abnormal (bukan posisi memanjang dengan kepala bagian terendah dari janin (Oxorn, H dan Fort W.R., 2010). Sejalan dengan pendapat oxorn bahwa kelainan letak janin terutama letak lintang membuat bagian janin selanjutnya tidak dapat memasuki PAP sehingga akan semakin berisiko untuk mengalami partus lama.

\section{Hubungan Umur Ibu Bersalin dengan Kejadian Partus Lama di RSU HAJI Medan Tahun 2014}

Terdapat kelompok kasus dan kelompok kontrol, umur responden 20 - 35 tahun lebih banyak dibandingkan umur responden $<20$ atau $>35$ tahun yaitu pada kelompok kasus sebanyak 55 orang $(43,65 \%)$ dan pada kelompok kontrol sebanyak 71 orang $(56,35 \%)$.

Di pandang dari umur ibu bersalin dengan kejadian partus lama, dinyatakan bahwa semakin muda atau semakin tua umur ibu akan berisiko untuk mengalami partus lama. Hasil uji statistik chi-square diperoleh $x^{2}=$ 9,56 dan nilai p.value adalah 0,002 berarti $p$ value $<0,05$ menunjukkan adanya hubungan yang bermakna kelompok ibu bersalin dengan partus lama pada umur ibu <20 tahun dan $>35$ tahun. Adapun nilai keeratan dapat dilihat dari nilai $O R=3,586(1,549-8,300)$, artinya resiko terjadinya partus lama pada ibu yang berumur $<20$ atau $>35$ tahun 3,586 kali dibandingkan ibu yang berumur 20-35 tahun.

Sesuai dengan teori bahwa umur ibu kurang dari 20 tahun dan lebih dari 35 tahun memiliki resiko tinggi yang kemungkinan akan memberikan ancaman kesehatan dan jiwa ibu maupun janin yang dikandungnya selama kehamilan, persalinan dan nifas. Reproduksi sehat atau dikenal dengan usia aman untuk kehamilan dan persalinan adalah umur 20 sampai 35 tahun (Mochtar, 2011).

Hal ini juga sesuai dengan penelitian Senewe, dkk (2009) proporsi ibu yang mengalami komplikasi saat persalinan pada kelompok umur kurang 20 dan 35 tahun keatas adalah $28 \%$, lebih besar daripada proporsi untuk yang berumur 21-34 tahun sebesar 22\%, OR yaitu 1,3 artinya pada ibu yang berumur kurang dari 20 tahun dan lebih dari 35 tahun berisiko untuk mengalami komplikasi persalinan sebesar 1,3 kali dibanding dengan ibu yang berumur 21-34 tahun.

Menurut asumsi penulis dari hasil uji chi-square dalam penelitian sesuai dengan teori bahwa umur mempunyai hubungan dengan kejadian partus lama, semakin muda usia ibu atau semakin tua usia ibu melahirkan akan semakin tinggi kemungkinan untuk terjadi partus lama. Namun, jumlah ibu yang mengalami partus lama umur 20 - 35 tahun lebih besar, ini bisa terjadi karena pada kasus tersebut walaupun ibu dengan umur reproduksi sehat tetapi ibu dengan faktor resiko tinggi lainnya untuk terjadi partus lama yaitu paritas atau >3, atau kelainan his, atau dengan CPD, atau KPD, atau dengan kelainan letak janin, atau dengan paritas 1 atau $>3$ dan kelainan letak janin, dengan paritas 1 atau >3, CPD, dan KPD, atau dengan paritas 1 atau $>3$ dan CPD, atau dengan CPD dan KPD

\section{Hubungan Paritas Ibu Bersalin dengan Kejadian Partus Lama di RSU HAJI Medan Tahun 2014}

Terdapat kelompok kasus dan kelompok kontrol, Paritas responden $2-3$ lebih banyak dibandingkan paritas 1 atau $>3$ yaitu pada kelompok kasus sebanyak 51 orang $(63,75 \%)$ dan pada kelompok kontrol sebanyak 74 orang (92,50\%). Di pandang dari paritas ibu bersalin dengan kejadian partus lama, dinyatakan bahwa ibu primipara dan multipara akan semakin berisiko untuk mengalami partus lama.

Hasil uji statistik chi-square diperoleh $x^{2}$ hitung $=$ 19,346 dan nilai p.value adalah $0,000, p$ value $<0,05$ menunjukkan adanya hubungan yang bermakna kelompok paritas ibu bersalin dengan kejadian partus lama pada paritas 1 atau $>3$. Adapun nilai keeratan dapat dilihat dari nilai $O R=7,013(2,71-18,11)$, artinya resiko terjadinya partus lama pada ibu dengan paritas 1 atau >3, 7,013 kali dibandingkan ibu dengan paritas $2-3$.

Sesuai dengan teori Manuaba (2010), ibu yang mempunyai anak lebih dari empat orang juga akan menambah resiko terhadap ibu dan bayinya, lebih - lebih jarak antara kehamilan kurang dari dua tahun, maka ibu akan lemah akibat seringnya hamil, melahirkan, menyusui, dan merawat anak - anaknya sehingga mengakibatkan berbagai masalah. Bahaya yang dapat terjadi pada ibu yang pernah melahirkan 4 kali atau lebih yakni persalinan lama, dan perdarahan pasca persalinan.

Hal ini juga sesuai dengan hasil penelitian di Subang Jawa Barat yang dilakukan oleh Olva (2001) dalam Dipta, TP (2010) dengan menggunakan desain penelitian case control study menemukan ibu yang 
mengalami partus tak maju kemungkinan 1,3 kali lebih besar yang paritasnya 1 dan $>3$ dibandingkan paritas 2-3.

Menurut asumsi penulis dari hasil uji chi-square dalam penelitian sesuai dengan teori. Paritas mempunyai hubungan dengan kejadian partus lama. Namun, dari penelitian pada kasus tersebut paritas 2-3 lebih banyak yang mengalami partus lama, bisa terjadi walaupun ibu memiliki jumlah anak yang baik tapi ibu memiliki faktor resiko tinggi lainnya terjadi partus lama yaitu umur $<20$ atau $>35$ tahun, atau kelainan his, atau dengan $\mathrm{CPD}$, atau $\mathrm{KPD}$, atau dengan kelainan letak janin, dengan umur $<20$ atau $>35$ tahun dan kelainan letak janin, dengan umur $<20$ atau $>35$ tahun dan CPD, atau dengan umur $<20$ atau $>35$ tahun, CPD dan KPD, atau ibu dengan CPD dan KPD.

\section{Hubungan Kelainan His pada Ibu Bersalin dengan Kejadian Partus Lama di RSU HAJI Medan Tahun 2014}

Terdapat kelompok kasus dan kelompok kontrol, Responden dengan tidak kelainan his lebih banyak dibandingkan dengan kelainan his yaitu pada kelompok kasus sebanyak 55 orang $(68,75 \%)$ dan pada kelompok kontrol sebanyak 79 orang $(98,75 \%)$. Di pandang dari keadaan his ibu bersalin dengan kejadian partus lama, dinyatakan bahwa proses persalinan dengan kelainan his pada his yang tidak adekuat akan semakin berisiko untuk mengalami partus lama.

Hasil uji statistik chi-square diperoleh $x^{2}=26,46$ dan nilai p.value adalah 0,000 berarti $p$ value $<0,05$ menunjukkan adanya hubungan yang bermakna antara kelompok kelainan his pada ibu bersalin dengan partus lama. Adapun nilai keeratan dapat dilihat dari nilai $O R=35,909$ (4,725-272,923), artinya resiko terjadi partus lama pada ibu bersalin dengan kelainan his 35,909 kali dibandingkan ibu dengan tidak kelainan his.

Sesuai dengan teori Prawirohardjo, 2011 bahwa faktor power atau his dan kekuatan yang mendorong janinkeluar adalah faktor yang sangat penting dalam prosespersalinan. Kelainan his menyebabkan kerintangan jalan lahir yang lazim terdapat pada setiap persalinan, tidak dapat diatasi sehingga persalinan mengalami hambatan atau kemacetan

Hasil ini juga sesuai penelitian Handa dan Laros dalam Prawirohardjo, 2011, mendiagnosis kemacetan fase aktif (tidak ada pembukaan selama 2 jam atau lebih) pada 5 persen nulipara aterm. Insiden ini belum berubah sejak tahun 1990-an. Kontraksi uterus yang kurang adekuat berhubungan dengan kejadian partus lama dimana kurang dari 180 satuan Montevideo, didiagnosis pada 80 persen ibu dengan kemacetan fase aktif selama persalinan

Menurut asumsi penulis dari hasil uji chi-square dalam penelitian sesuai dengan teori. Kelainan his mempunyai hubungan dengan kejadian partus lama. Namun, dari penelitian pada kasus tersebut responden tidak dengan kelainan his lebih banyak yang mengalami partus lama daripada dengan kelainan his, bisa terjadi walaupun dengan his yang adekuat tetapi ibu memiliki faktor resiko tinggi lainnya terjadi partus lama yaitu umur $<20$ atau $>35$ tahun, atau paritas 1 atau $>3$, atau dengan CPD, atau KPD, atau dengan kelainan letak janin, dengan umur $<20$ atau
$>35$ tahun dan kelainan letak janin, dengan umur $<20$ atau $>35$ tahun dan CPD, atau dengan umur $<20$ atau $>35$ tahun, CPD dan KPD, atau ibu dengan CPD dan KPD.

\section{Hubungan CPD dengan Kejadian Partus Lama di RSU HAJI Medan Tahun 2014}

Terdapat kelompok kasus dan kelompok kontrol, Responden tidak dengan CPD lebih banyak dibandingkan dengan CPD yaitu pada kelompok kasus sebanyak 58 orang $(72,50 \%)$ dan pada kelompok control sebanyak 80 orang (100\%). Di pandang dari keadaan panggul ibu bersalin dengan kejadian partus lama, dinyatakan bahwa ibu dengan panggul yang sempit akan menyebabkan ketidaksesuaian dengan kepala janin yang membuat kepala tertahan di tulang panggul ibu sehingga akan semakin berisiko untuk mengalami partus lama.

Berdasarkan analisis bivariat dengan Uji statistik chi-square diperoleh $x^{2}$ hitung $=25,51$ dan nilai $p$.value adalah $0,000, p$ value $<0,05$ menunjukkan adanya hubungan yang bermakna kelompok CPD pada ibu bersalin dengan kejadian partus lama pada ibu bersalin dengan CPD.

Sesuai dengan teori kehamilan pada ibu dengan tinggi badan $<145 \mathrm{~cm}$ dapat terjadi CPD, kondisi luas panggul ibu tidak sebanding dengan kepala bayi, sehingga pembukaannya berjalan lambat dan akan menimbulkan komplikasi obstetri (Dipta,TP 2010). Hal ini juga sesuai dengan hasil penelitian di Nigeria Utara dari seluruh ibu yang mengalami persalinan macet, proporsi wanita dengan panggul sempit memiliki tinggi badan < $145 \mathrm{~cm}$ sebesar $40 \%$, tinggi badan $150 \mathrm{~cm}$ sebesar 14\% dan tinggi badan $160 \mathrm{~cm}$ sebesar $1 \%$ (Farihaalthafunnisa,2011)

Menurut asumsi penulis dari hasil uji chi-square dalam penelitian sesuai dengan teori. Ibu bersalin dengan CPD mempunyai hubungan bermakna dengan kejadian partus lama. Namun, dari penelitian tersebut jumlah ibu bersalin dengan tidak CPD lebih besar mengalami partus lama daripada dengan CPD bisa terjadi karena dapat dilihat ibu tidak dengan CPD melainkan ibu memiliki faktor resiko tinggi lainnya untuk terjadi partus lama yaitu umur $<20$ atau $>35$ tahun, atau dengan paritas 1 atau $>3$, atau kelainan his, atau KPD, atau kelainan letak janin, atau umur $<20$ atau $>35$ tahun dan kelainan letak janin, atau paritas 1 $>3$ dan kelainan letak janin, atau umur <20 atau >35 tahun dan paritas $1>3$, atau umur $<20$ atau $>35$ tahun, paritas 1 atau $>3$, dan kelainan letak janin.

\section{Hubungan KPD dengan Kejadian Partus Lama di RSU HAJI Medan Tahun 2014}

Terdapat kelompok kasus dan kelompok kontrol, Responden tidak dengan KPD lebih banyak dibandingkan dengan KPD yaitu pada kelompok kasus sebanyak 67 orang $(83,75 \%)$ dan pada kelompok kontrol sebanyak 79 orang $(98,75 \%)$. Di pandang dari keadaan ketuban ibu bersalin dengan kejadian partus lama, dinyatakan bahwa ibu dengan ketuban pecah dini akan menyebabkan persalinan berlangsung lebih dari 12 jam sehingga akan semakin berisiko untuk mengalami partus lama. 
Hasil uji statistik chi-square diperoleh $x^{2}=11,27$ dan nilai p.value adalah 0,001 berarti $p$ value $<0,05$ menunjukkan adanya hubungan yang bermakna kelompok ibu bersalin dengan partus lama pada keadaan KPD. Adapun nilai keeratan dapat dilihat dari nilai $O R=15,33$ (1,95-120,25), artinya resiko terjadinya partus lama pada ibu dengan KPD, 15,33 kali dibandingkan ibu tidak dengan KPD. Sesuai dengan teori, KPD dibagi menjadi dua kategori yaitu KPD preterm yaitu sebelum usia kehamilan 37 minggu dan KPD yang memanjang yaitu KPD yang terjadi pada akhir kehamilan dengan lebih dari 12 jam sebelum waktunnya melahirkan sehingga berakibat pada kejadian partus lama (Rukiyah, Aiyeyeh, 2010)

Hal ini juga sesuai dengan penelitian Park, dkk menyimpulkan bahwa wanita dengan Ketuban Pecah Dini mempunyai rata - rata durasi waktu kala II persalinan yang lebih lama dan mempunyai angka persalinan seksio sesarea yang lebih tinggi karena kegagalan kemajuan persalinan daripada wanita dengan ketuban utuh (Farihaalthafunnisa,2011). Menurut asumsi penulis dari hasi uji chi-square dalam penelitian di atas sesuai dengan teori, terdapat hubungan yang bermakna antara KPD dengan kejadian partus lama. Namun, dari penelitian pada kasus tersebut ibu tidak dengan KPD lebih banyak mengalami partus lama daripada dengan KPD bisa terjadi karena dapat dilihat ibu tidak dengan KPD melainkan ibu dengan resiko tinngi lainnya untuk terjadi partus lama yaitu umur $<20$ atau $>35$ tahun, atau paritas 1 atau $>3$, atau kelainan his, CPD, atau kelainan letak janin, atauparitas 1 atau $>3$ dan kelainan letak janin, atau umur $<20$ atau $>35$ tahun, paritas $1>3$ dan kelainan letak janin, atau umur $<20$ atau $>35$ tahun, paritas $1>3$ dan CPD.

\section{Hubungan Kelainan Letak Janin dengan Kejadian Partus Lama di RSU HAJI Medan Tahun 2014}

Terdapat kelompok kasus dan kelompok kontrol, Responden tidak dengan Kelainan Letak Janin lebih banyak dibandingkan dengan Kelainan Letak Janin yaitu pada kelompok kasus sebanyak 60 orang $(75,00 \%)$ dan pada kelompok control sebanyak 78 orang $(97,50 \%)$. Di pandang dari keadaan letak janin dengan kejadian partus lama, dinyatakan bahwa ibu dengan kelainan letak janin terutama letak lintang membuat bagian janin selanjutnya tidak dapat memasuki PAP sehingga akan semakin berisiko untuk mengalami partus lama.

Hasil uji statistik chi-square diperoleh $x^{2}=17,08$ dan nilai p.value adalah 0,000 berarti $p$ value $<0,05$ menunjukkan adanya hubungan yang bermakna kelompok ibu bersalin dengan partus lama pada keadaan kelainan letak janin. Adapun nilai keeratan dapat dilihat dari nilai $O R=13,00 \quad(2,92-57,8)$, artinya resiko terjadinya partus lama pada ibu dengan kelainan letak janin 13,00 kali dibandingkan ibu tidak dengan kelainan letak janin

Hal ini sesuai dengan teori bahwa presentasi dahi tidak dapat dilahirkan dengan kondisi normal kecuali bila bayi kecil atau pelvis luas karena berawal dari persalinan lama yang dapat menimbulkan komplikasi buruk bagi ibu maupun janin, persalinan dilakukan dengan tindakan caesarea. (Oxorn, H dan Fort W.R., 2010. Hal ini juga sesuai dengan hasil penelitian Eka Trismiyana, dkk di
RSUD Dr. H. Abdul Moeloek Propinsi Lampung 2011, menunjukan adanya hubungan signifikan letak janin dengan partus lama $(p=0,000)$ Odd Rasio $(\mathrm{OR})=4,5$.

Menurut asumsi penulis dari hasil uji chi-square dalam penelitian di atas sesuai dengan teori, terdapat hubungan yang bermakna antara kelainan letak janin dengan kejadian partus lama. Namun, dari penelitian tersebut ibu bersalin dangan tidak kelainan letak janin lebih banyak mengalami partus lama daripada dengan kelainan letak janin, bisa terjadi karena dapat dilihat pada kasus tersebut ibu tidak dengan kelainan letak janin, melainkan ibu memiliki faktor resiko tinggi lainnya untuk terjadi partus lama yaitu umur $<20$ atau $>35$ tahun, atau paritas 1 atau $>3$, atau kelainan his, atau CPD, atau KPD, atau paritas 1 atau $>3$ dan kelainan letak janin, atau umur $<20$ atau $>35$ tahun, paritas 1 atau $>3$, dan CPD, atau paritas $1>3$, CPD, dan $\mathrm{KPD}$, atau umur $<20$ atau $>35$ tahun, paritas $1>3$ dan KPD, atau umur $<20$ atau $>35$ tahun, CPD, dan KPD.

\section{SIMPULAN DAN SARAN}

\section{Simpulan}

1. Dari 80 responden sebagai kasus yang mengalami partus lama lebih banyak pada umur 20-35 tahun sebesar 55 orang $(68,75)$, paritas 2-3 lebih banyak yaitu sebesar 51 orang $(63,75)$, dengan tidak kelainan his lebih banyak yaitu 55 orang $(68,75 \%)$, dengan tidak CPD lebih banyak yaitu sebesar 58 orang $(72,50 \%)$, dengan tidak KPD lebih banyak yaitu sebesar 67 orang $(83,75 \%)$, dengan tidak kelainan letak janin lebih banyak yaitu sebesar 60 orang $(75,00 \%)$

2. Ada hubungan yang bermakna antara umur ibu bersalin dengan kejadian partus lama, dimana nilai $p$ value $=0,002<0,05$

3. Ada hubungan yang bermakna antara paritas ibu bersalin dengan kejadian partus lama, dimana nilai $p$ value $=0,000<0,05$

4. Ada hubungan yang bermakna antara kelainan his dengan kejadian partus lama, dimana nilai $p$ vlaue $=0,000<0,05$

5. Ada hubungan yang bermakna antara CPD dengan kejadian partus lama, dimana nilai $p$ value $=0,000<0,0$

6. Ada hubungan yang bermakna antara KPD dengan kejadian partus lama, dimana nilai $p$ value $=0,001<0,05$

7. Ada hubungan yang bermakna antara Kelainan Letak Janin dengan kejadian partus lama, dimana nilai $p$ value $=0,000<0,05$

\section{B. Saran}

Adapun saran yang akan diberikan sehubungan dengan penelitian ini adalah

1. Bagi Organisasi Profesi

Disarankan kepada Organisasi Profesi meningkatkan kegiatan seminar dan pelatihan khusus pada seluruh tenaga kesehatan mandiri 
maupun komunitas dalam pencegahan dan penanganan rujukan cepat pada kasus partus lama

2. Bagi Kepala RSU Haji Medan

Sebaiknya pihak RSU Haji Medan meningkatkan kegiatan seminar atau pelatihan khusus bagi tenaga kesehatan di RSU Haji Medan mengenai partus lama sehingga tenaga kesehatan memiliki keahlian dalam penanganan kasus partus lama.

3. Bagi peneliti selanjutnya Diharapkan penelitian ini dijadikan sebagai masukan yang bermanfaat bagi peneliti selanjutnya dengan cakupan yang lebih luas.

\section{DAFTAR PUSTAKA}

Manuaba, IBG., 2010. Ilmu Kebidanan, Penyakit Kandungan, dan KB untuk Pendidikan Bidan Edisi 2. Jakarta : EGC

Mochtar, R., 2012. Sinopsis Obstetri Fisiologi dan Patologi. Jakarta : EGC

Notoadmojo., 2010. Metodologi Penelitian Kesehatan. Jakarta : PT. Rineka Cipta

Oxorn, H dan Fort W.R., 2010. Ilmu Kebidanan Patologi \& Fisiologi Persalinan. Jakarta : EGC

Prawirohardjo, S., 2007. Buku Panduan Praktis Pelayanan Kesehatan Maternal dan Neonatal. Jakarta : Yayasan Bina Pustaka

., 2009. Buku Acuan Nasional Pelayanan Kesehatan Maternal dan Neonattal. Jakarta : Yayasan Bina Pustaka ., 2011. Ilmu Kebidanan. Jakarta : Bina Pustaka

Rukiyah Aiyeyeh dan Yulianti Lia., 2010. Asuhan Kebidanan IV (Patologi Kebidanan). Jakarta: Trans Info Media

Sumarah., dkk. 2008. Perawatan Ibu Bersalin. Yogyakarta: Fitramaya

Afifah T,dkk,. 2008. Karakteristik Ibu Bersalin dengan Partus Lama..
http:/adsb.Kompasds.com/new/www/delivery/ ck.php?n=a37da3 Diakses tanggal 03 Februari 2015

Dinkes., 2011. Profil Kesehatan Indonesia Tahun 2011. www.depkes.go.id. Diakses tanggal 15 Januari 2015.

Dipta, TP,. 2010. Karakteristik Ibu Berslin dengan Partus Lama

http://repository.usu.ac.id/bitstream/1234567 89/20158/5/Chapter\%20I pdf.Diakses tanggal 13 Januari 2015.

SDKI., 2012. Angka Kematian Ibu dan Bayi. Html. Diakses tanggal 18 Januari 2015

Senewe, dkk., 2009. Faktor Risiko Kejadian Partus Lama di RSIA Siti Fatimah Makassar Tahun 2009. http://www.scribd.com. diakses tanggal 3 Februari 2015

Skripsipedia.com., Karakteristik Ibu Bersalin dengan Partus Lama di RShttp://www.skripsipedia.com/2010/04/kara kteristik-ibu-bersalinpartus lama . diakses tanggal 22 Desember 2014

Suredi., 2012. Fenomena Tingginya AKI. http://www.infodokterku.com/peta-situsinfodokterku-com/16-data/data/222fenomena-tingginya-angka-kematian-ibu-akiatau-mmr-berdasarkan-sdki-2012. diakses tanggal 03 Februari 2015

. 2010 Latar Belakang Faktor - Faktor yang Berhubungan dengan Kejadian Partus Lama. http://edoqs.com/pdf/bab-1-pendahuluan-11latar-belakang-usu-institutionalf28c054b77a4daf19d050225fce3e479. diakses tanggal 13 Januari 2015

WHO, 2010. Maternal Mortality. http://www.who.int/gho/maternal_mortality/e n/diakses tanggal 02 Februari 2015. 